\title{
Moving Ice and Satellites: The Motion of Crevasses in Antarctica
}

\author{
Amelia Carolina Sparavigna ${ }^{1}$
}

\author{
${ }^{1}$ Department of Applied Science and Technology, Politecnico di Torino, Italy
}

\begin{abstract}
Antarctica is a remote and hostile continent, the study of which is fundamental because of the role it has on oceans and Earth's climate. Affected by the global warming phenomenon, Antarctica requires a constant monitoring of the status and motion of its ice. This monitoring can be achieved by means of satellites. Here we will show, by using Google Earth imagery, some evidence of the ice flows in this continent. In particular, we will discuss the motion of some surface features of the ice shelves, which can be considered as the surface expression of basal crevasses. We can measure the rate of their motion too.
\end{abstract}

Keywords: Ice flow, Satellite Images, Geophysics, Climate Change, Global Warming, Crevasses, Basal Crevasses, Antarctica, Amery Ice Shelf, Larsen C Ice Shelf

\section{Introduction}

Antarctica is a remote and hostile continent, but the study of its environment is fundamental for the role that this continent has on oceans and Earth's climate. Let us remember that it is the Antarctic science, which can first reveal the impact of human activity on our world. For instance, in 1985, the scientists at British Antarctic Survey first evidenced the damage of the ozone layer, by discovering a hole in it above Antarctica. In this manner, the Antarctic science warned people of the damage produced in the Earth's atmosphere by the use of some chemicals.

In the last years, in particular, the Antarctic science has focused on the effects of the global warming on ice loss. Actually, a recent study has shown that West Antarctica is one the fastest-warming places on Earth [1]. An article published in 2018 [2] has also estimated the ice loss during the period from 1992 to 2017. Most ice loss occurred in West Antarctica and the Antarctic Peninsula.

To collect more information on this continent, a constant monitoring of the status and motion of the ice is necessary. This monitoring can be achieved through satellites. By means of them, in 2011, it had been published the first map showing how the ice moves across the entire Antarctic continent [3]. The measurements were made by radar instruments on satellites between 1996 and 2009 [4,5]. The mapping show areas that are moving as quickly as a few kilometres per year. We can also see areas where the movement is of a few centimetres per year. As evidenced by the study, the slowest moving ice is along the divides, which are separating the glacier basins.

Several studies on moving ice in different regions of Antarctica have preceded this map of the entire continent. We have studies, such as that proposed in [6], based on the results of satellite radar interferometry (SRI), and studies, such as [7], where Global Positioning System (GPS) data have been used. In [6], it was the Lambert Glacier Drainage Basin under investigation; in [7], GPS observation data were concerning the Amery Ice Shelf. Other observations about Antarctica are given in [8-18].

Here will show that also in Google Earth imagery we can find evidences of the ice flows in Antarctica. We will focus in particular on the motion of those surface features, which are considered as the surface expression of basal crevasses.
Moving surface features
As stressed in [19], NASA has the Earth Observation Program, which is monitoring Arctic and Antarctic from many years. In the framework of this program, Operation IceBridge is an ongoing program of NASA, which is studying the motion of the ice [20]. From 2003 to 2009, NASA used the ICESat satellite, which was retired in 2009. This fact was leaving NASA without a satellite dedicated to ice observance. The next-generation satellite, ICESat-2, was launched in September 2018. To maintain the annual observations of ice sheets, NASA introduced the IceBridge program, in order to "bridge the gap" between the satellite missions. The program utilizes aircraft platforms. IceBridge flights began in March 2009, for an Arctic Spring campaign, followed by the 
first Austral Spring campaign in October 2009 [20].

Operation IceBridge has spent much of the past decade monitoring the Antarctic ice sheet for signs of cracks and flows [19], in order to determine how and at what rate the ice sheet is changing. Actually, the method is similar to that used for the sand dunes [2124]. In these references [21-24], we discussed the use of the time series of satellite images (in particular of Google Earth) to follow the motion of the dunes. In the case of the ice flow of course, instead of observing dunes, we can observe the motion of large ice cracks, crevasses, or other features, in the time series of images. Here in the following we shows some examples, using Google Earth imagery.

\section{Amery Ice Shelf}

The Amery Ice Shelf is a broad ice shelf in Antarctica (in [25], a map of the shelf is given). In the upper part of Figure 1, we can see an area of one of the glaciers - the above-mentioned Lambert Glacier is one of them - which are flowing into the Amery Ice Shelf. In the lower part of the Figure 1, we can see two images from a time series of Google Earth, one recorded on 31 December 2013, the other recorded on 31 December 2016. The visibility of a part of these satellite images was enhanced by means of the GIMP Retinex filter (a discussion on the use of this filter has been proposed in [26]). In this manner, we can see clearly the crevasses in the ice. They are moving. The 2013 and 2016 images are combined in the panel on the right of Fig.1, in the manner discussed in [24]: we can see that these features moved of about 180 meters during a time interval of three year, that is, they moved of about 60 meters per year. By continuing the observation by means of satellite images, we can appreciate any change in the motion rate.

In the Figure 2, we can see some different features on the surface of the Amery shelf. After enhancing the Google Earth images by means of GIMP Retinex, we can see the presence of lines of surface deformation. These lines are almost perpendicular of the flow direction. In [27], it seems that these features are considered simply as crevasses.

In the Figure 3, we show the two panels of the Figure 2 combined, as discussed in [24], to evidence the motion of these ice surface features. The red segments point the position of the features on 31 December 2016, and the blue segments the position on 31 December 2013. We can see that these features moved of about 960 meters during a time interval of three year, that is, they moved of about 320 meters per year. Therefore, using a time series of satellite images, the motion of these features can be easily monitored.

\section{High resolution images of basal crevasses}

In [28], the study of the Larsen C ice shelf was proposed. The Larsen Ice Shelf is a long ice shelf, in the Northwest part of the Weddell Sea, extending along the east coast of the Antarctic Peninsula. In particular, the Larsen Ice Shelf is a series of shelves, each of which is in a distinct embayment along the coast. Larsen $\mathrm{C}$ is the largest one. The ice shelf originally covered an area of 85,000 square kilometres; it now covers an area of 67,000 square kilometres [29]. In the Figure 4, we can see two images from Google Earth of the Larsen C Shelf. In the upper panel, longitudinal and transverse (to the flow) surface structures are visible. In [28], the transverse textures are interpreted simply as crevasses. These features are the same textures that we have given in the Figure 2. In Ref.30, these features are proposed and discussed as surface expressions of basal crevasses. In Ref.31, the plastic deformation of ice due to the presence of these crevasses is discussed.

The Figure 5, obtained by a Google Earth time series, shows that they move.

In the case of the Larsen C Shelf, Google Earth gives us the possibility to observe the above- mentioned crevasse features with a high resolution. Here some of such images are given in the Figures 6 and 7. What is interesting is that these images can show the evolution of the features when they reach the edge of the shelf. We can see that the surface features become huge cracks in the ice. Further analyses by means of Google Earth, can evidence other cases of such behaviour.

\section{Conclusion}

In this article, we have shown that, by means of the time series of satellite images, we can observe the motion, and measure its rate, of the surface features of ice flows. In particular, we have investigated those surface features, which correspond to the basal crevasses in the ice shelves (Amery and Larsen $\mathrm{C}$ ice shelves). Further analyses, made by means of Google Earth, are under consideration to search evidence of the motion of these features in other ice shelves.

\section{References}

1. Bromwich, D. H., Nicolas, J. P., Monaghan, A. J., Lazzara, M. A., Keller, L. M., Weidner, G. A., \& Wilson, A. B. (2013). Central West Antarctica among the most rapidly warming regions on Earth. Nature Geoscience, 6(2), 139. DOI: $10.1038 /$ ngeo1671

2. IMBIE team (2018). Mass balance of the Antarctic ice sheet from 1992 to 2017. Nature, 558, 219-222. DOI: 10.1038/s41586-018-0179-y

3. First Map of Antartica's Moving Ice, (2011). Available at https://earthobservatory.nasa.gov/ images/ 51781/ first-mapof-antarticas-moving-ice

4. Buis, A., \& Cole, S. (2011). NASA research leads to first complete map of Antarctic ice flow. NASA. Available at 
https://www.nasa.gov/topics/earth/features/antarctica2011081 8.html

5. Rignot, E., Mouginot, J., \& Scheuchl, B. (2011). Ice flow of the Antarctic ice sheet. Science Express. Available at http://www.esa.int/ Our_Activities/ Observing_the_Earth/ Space_for_our_climate/

Revealed_an_ice_sheet_on_the_move

6. Goldstein, R. M., Engelhardt, H., Kamb, B., \& Frolich, R. M. (1993). Satellite radar interferometry for monitoring ice sheet motion: application to an Antarctic ice stream. Science, 262(5139), 1525-1530. DOI: 10.1126/science.262.5139.1525

7. Manson, R., Coleman, R., Morgan, P., \& King, M. (2000). Ice velocities of the Lambert Glacier from static GPS observations. Earth, planets and space, 52(11), 1031-1036. DOI: /10.1186/BF03352326

8. Zhang, X., \& Andersen, O. B. (2006). Surface ice flow velocity and tide retrieval of the Amery ice shelf using precise point positioning. Journal of Geodesy, 80(4), 171176. DOI: 10.1007/s00190-006-0062-8

9. Yu, J., Liu, H., Jezek, K. C., Warner, R. C., \& Wen, J. (2010). Analysis of velocity field, mass balance, and basal melt of the Lambert Glacier-Amery Ice Shelf system by incorporating Radarsat SAR interferometry and ICESat laser altimetry measurements. Journal of Geophysical Research: Solid Earth, 115, B11102. DOI: 10.1029/2010JB007456

10. Shengkai, Z., Dongchen, E., Zemin, W., Yuansheng, L., Bo, J., \& Chunxia, Z. (2008). Ice velocity from static GPS observations along the transect from Zhongshan station to Dome A, East Antarctica. Annals of Glaciology, 48, 113-118. DOI: $10.3189 / 172756408784700716$

11. King, M. A. (2002). The dynamics of the Amery Ice Shelf from a combination of terrestrial and space geodetic data (Doctoral dissertation, University of Tasmania). Open Access Repository: https://eprints.utas.edu.au/20510/

12. Damaske, D., \& McLean, M. (2005). An aerogeophysical survey south of the Prince Charles Mountains, east Antarctica. Terra Antartica, 12(1/2), 87.

13. Testut, L., Hurd, R., Coleman, R., Rémy, F., \& Legrésy, B. (2003). Comparison between computed balance velocities and GPS measurements in the Lambert Glacier basin, East Antarctica. Annals of Glaciology, 37, 337-343. DOI: 10.3189/172756403781815672

14. Sunil, P. S., Reddy, C. D., Ponraj, M., Dhar, A., \& Jayapaul, D. (2007). GPS determination of the velocity and strain-rate fields on Schirmacher Glacier, central Dronning Maud Land, Antarctica. Journal of Glaciology, 53(183), 558-564. DOI: 10.3189/002214307784409199

15. Allison, I. (2003). The AMISOR project: ice shelf dynamics and ice-ocean interaction of the Amery Ice Shelf. FRISP Report, 14, 1-9.

16. Young, N. W., \& Hyland, G. (2002). Velocity and strain rates derived from InSAR analysis over the Amery Ice Shelf, East Antarctica. Annals of Glaciology, 34, 228-234. DOI: 10.3189/172756402781817842

17. King, M. A., Coleman, R., Morgan, P. J., \& Hurd, R. S. (2007). Velocity change of the Amery Ice Shelf, East
Antarctica, during the period 1968-1999. Journal of Geophysical Research: Earth Surface, 112(F1). DOI: 10.1029/2006JF000609

18. Sunil, P. S., Reddy, C. D., Ponraj, M., Dhar, A., \& Jayapaul, D. (2007). GPS determination of the velocity and strain-rate fields on Schirmacher Glacier, central Dronning Maud Land, Antarctica. Journal of Glaciology, 53(183), 558-564. DOI: $10.3189 / 002214307784409199$

19. Williams, M. (2018). This is ice in Antarctica, flowing in slow motion like water going through river rapids. Universe Today. Available at https://phys.org/news/ 2018-01-iceantarctica-motion-river-rapids.html

20. Vv. Aa.

(2019). https://en.wikipedia.org/wiki/Operation_IceBridge

21. Sparavigna, A. C. (2013). A study of moving sand dunes by means of satellite images. International Journal of Sciences, 2(8):33-42. DOI: $10.18483 / \mathrm{ijSci} .229$

22. Sparavigna, A. C. (2013). The GNU Image Manipulation Program Applied to Study the Sand Dunes (September 4, 2013). International Journal of Sciences 2(09):1-8. DOI: 10.18483/ijSci.289

23. Sparavigna, A. C. (2013). A case study of moving sand dunes: The barchans of the Kharga Oasis. International Journal of Sciences, 2(8):95-97 DOI: 10.18483/ijSci.241

24. Sparavigna, A. C. (2016). Analysis of the motion of some Brazilian coastal dunes. International Journal of Sciences, 5(1), 22-31. DOI: 10.18483/ijSci.905

25. Zhao, C., Cheng, X., \& Hui, F. M. (2013). Monitoring the Amery Ice Shelf front during 2004-2012 using ENVISAT ASAR data. Adv Polar Sci, 24(2), 133-137. Advances in Polar Science 24(2):133-137. DOI: 10.3724/SP.J.1085.2013.00133

26. Sparavigna, A. C. (2015). Gimp Retinex for Enhancing Images from Microscopes, International Journal of Sciences 4(06), 72-79. DOI: 10.18483/ijSci.758

27. Liu, Y., Cheng, X., Hui, F., Wang, X., Wang, F., \& Cheng, C. (2014). Detection of crevasses over polar ice shelves using Satellite Laser Altimeter. Science China Earth Sciences, 57(6), 1267-1277. DOI: 10.1007/s11430-013-4796-x

28. Glasser, N. F., Kulessa, B., Luckman, A., Jansen, D., King, E. C., Sammonds, P. R., Scambos, T.A., \& Jezek, K. C. (2009). Surface structure and stability of the Larsen C ice shelf, Antarctic Peninsula. Journal of Glaciology, 55(191), 400-410. DOI: 10.3189/002214309788816597

29. The Editors of Encyclopaedia Britannica (2019). Available at https://www.britannica.com/ place/ Larsen-Ice-Shelf

30. Luckman, A., Jansen, D., Kulessa, B., King, E. C., Sammonds, P., \& Benn, D. I. (2012). Basal crevasses in Larsen C Ice Shelf and implications for their global abundance, The Cryosphere, 6, 113-123. DOI: 10.5194/tc-6113-2012

31. Bassis, J. N., \& Ma, Y. (2015). Evolution of basal crevasses links ice shelf stability to ocean forcing. Earth and Planetary Science Letters, 409, 203-211. DOI: 10.1016/j.epsl.2014.11.003 

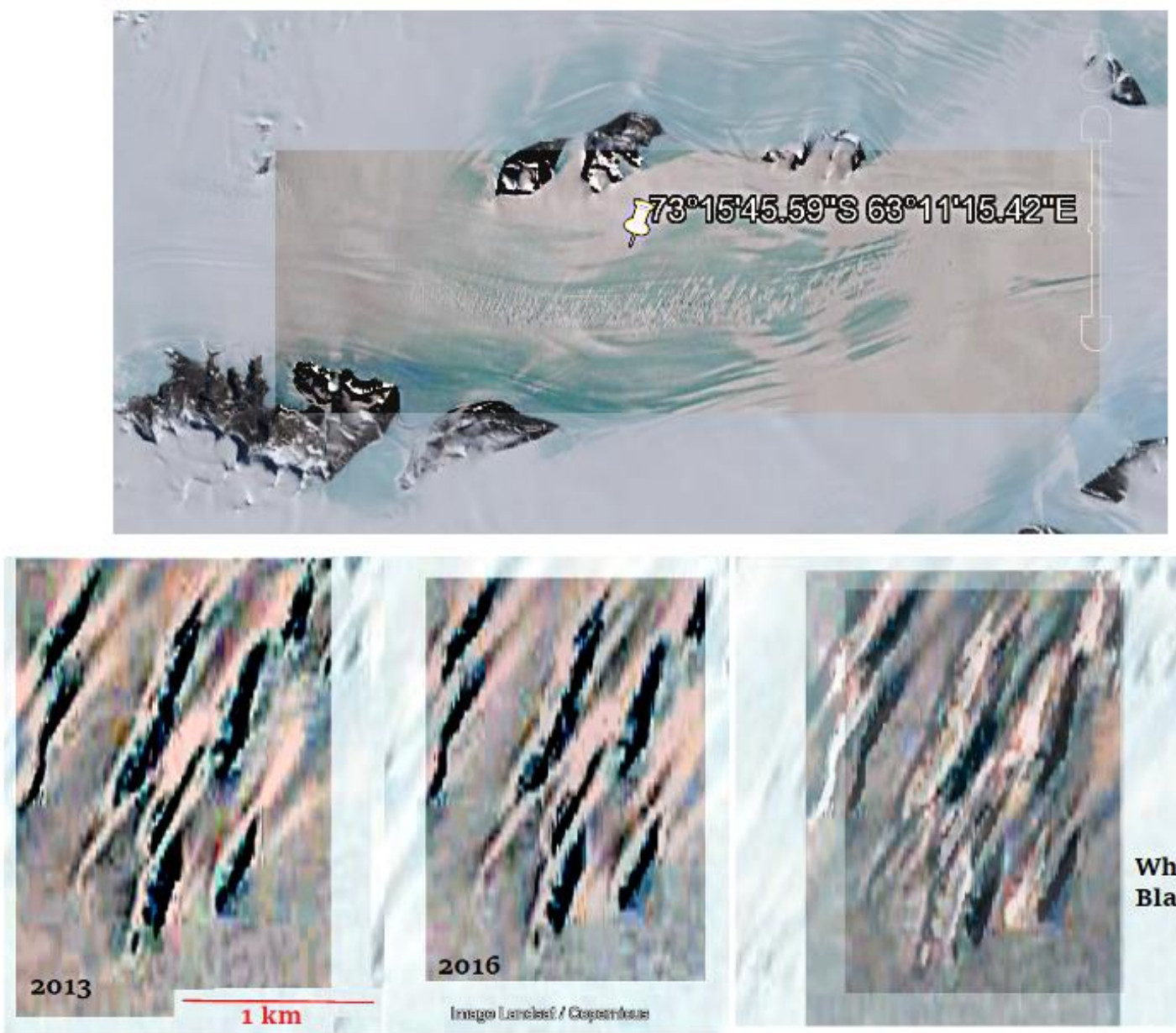

White (2013)

Black (2016)

Figure 1: Ice flow of one of the glaciers flowing into the Amery Ice Shelf. The pin is at coordinates $73^{\circ} 15^{\prime} 45.59^{\prime \prime}$ $\mathrm{S}, 63^{\circ} 11^{\prime} 15.42^{\prime}$ ' E. In the lower left panel, we can see an image of Google Earth recorded on 31 December 2013; in the panel in the middle, we can see an image recorded on 31 December 2016. The visibility of a part of these satellite images was enhances by means of GIMP Retinex filter. This filter allows improving the details in images. In this manner, we can see clearly the crevasses in the ice. They are moving. The 2013 and 2016 images are combined in the panel on the right, in the manner discussed in [24]. In the panel, the crevasses as seen in 2016 are black, whereas the crevasses as seen in 2013 are rendered in white. We can see that these features moved of about 180 meters during a time interval of three year, that is, they moved of about 60 meters per year. 


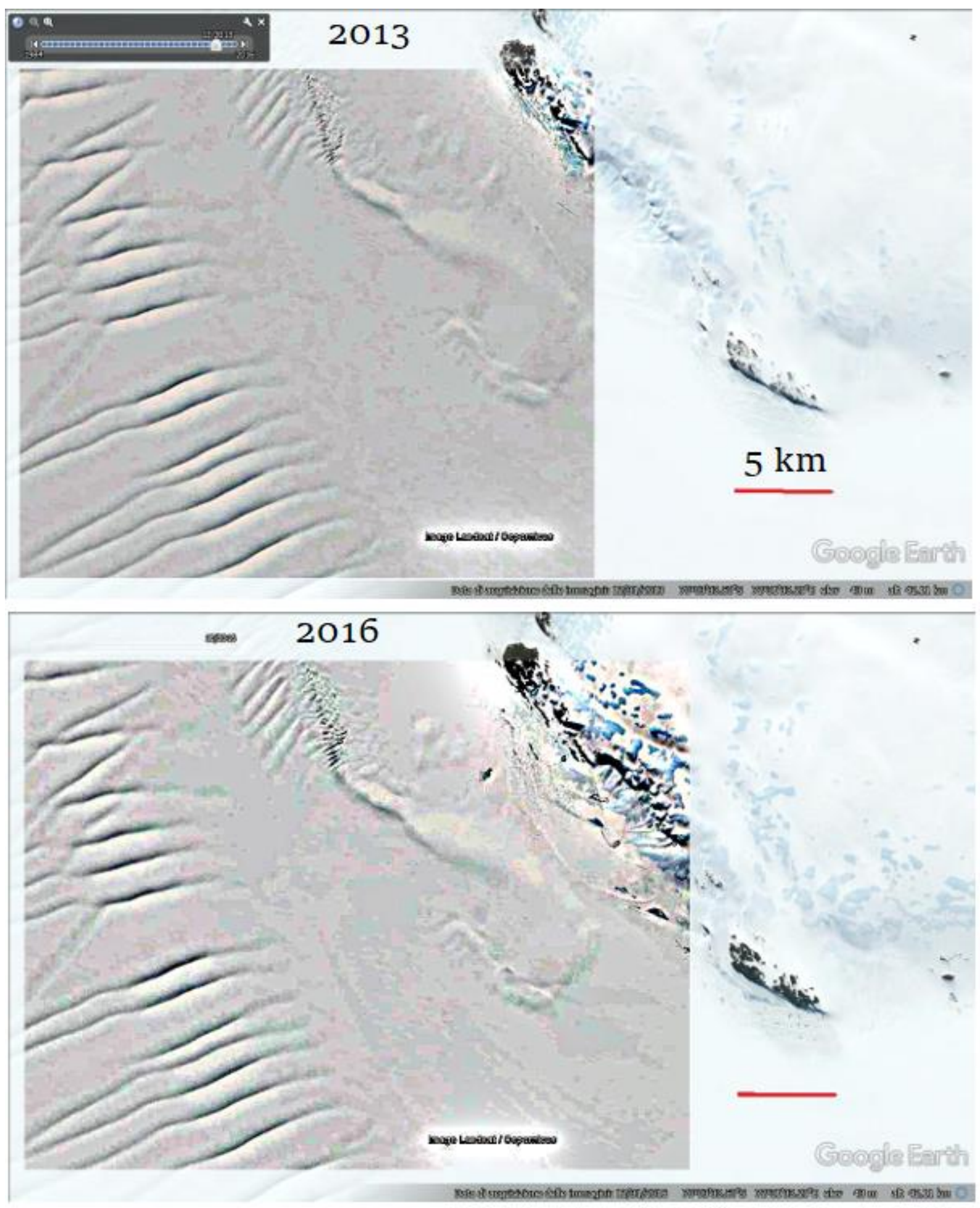

Figure 2: The upper panel shows an image recorded on 31 December 2013, the lower panel that recorded on 31 December 2016. The visibility of a part of the satellite images was increased by means of GIMP Retinex filter. In this manner, we can see the surface features of the shelf enhanced. These features are moving. 


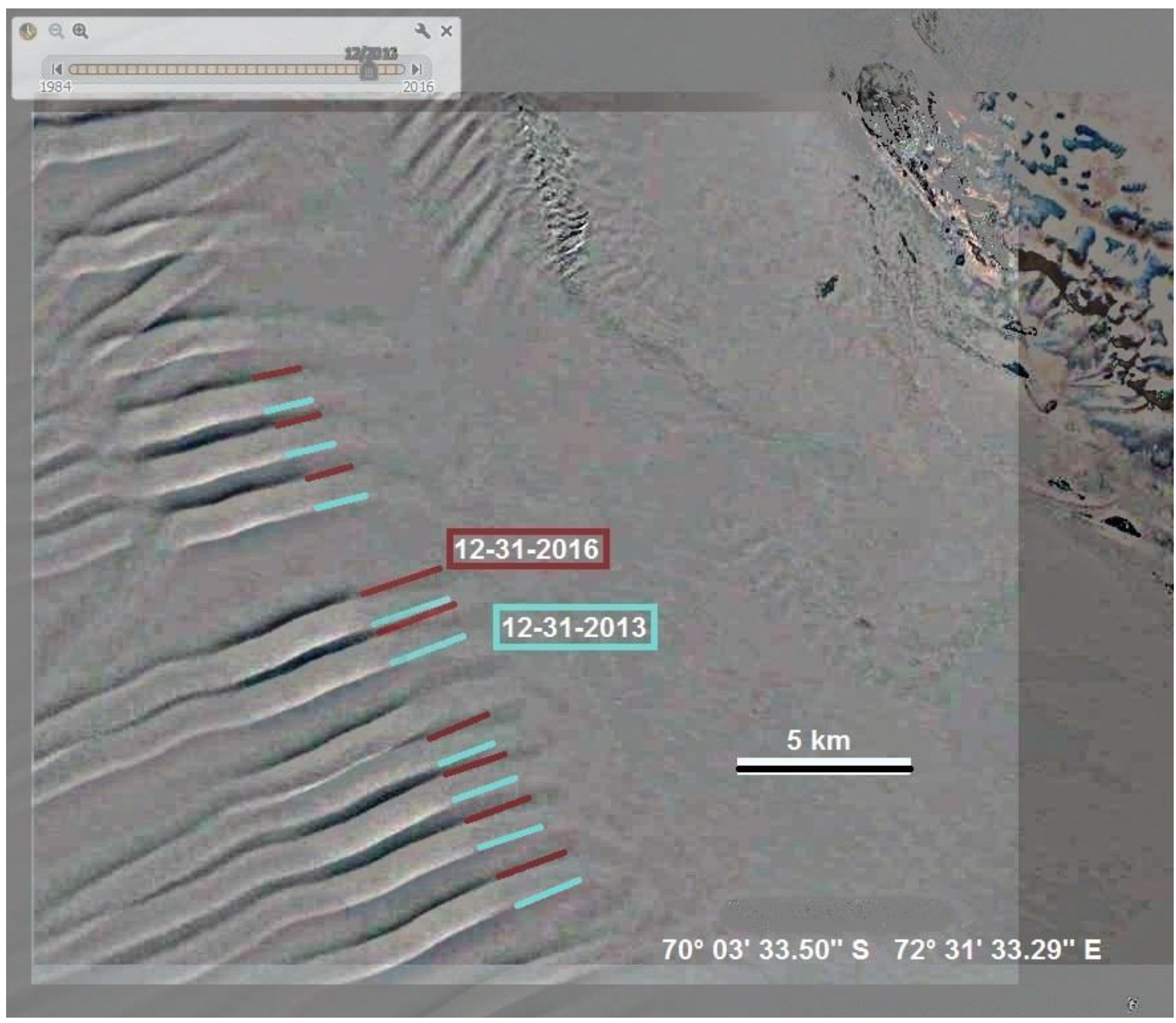

Figure 3: The image shows the two panels of Figure 2 combined, as discussed in [24], to see the motion of the ice surface features. The red segments point the position of the features on 31 December 2016, and the blue segments the position on 31 December 2013. We can see that these features moved of about 960 meters during the time interval of three year, that is, they moved of about 320 meters per year. 


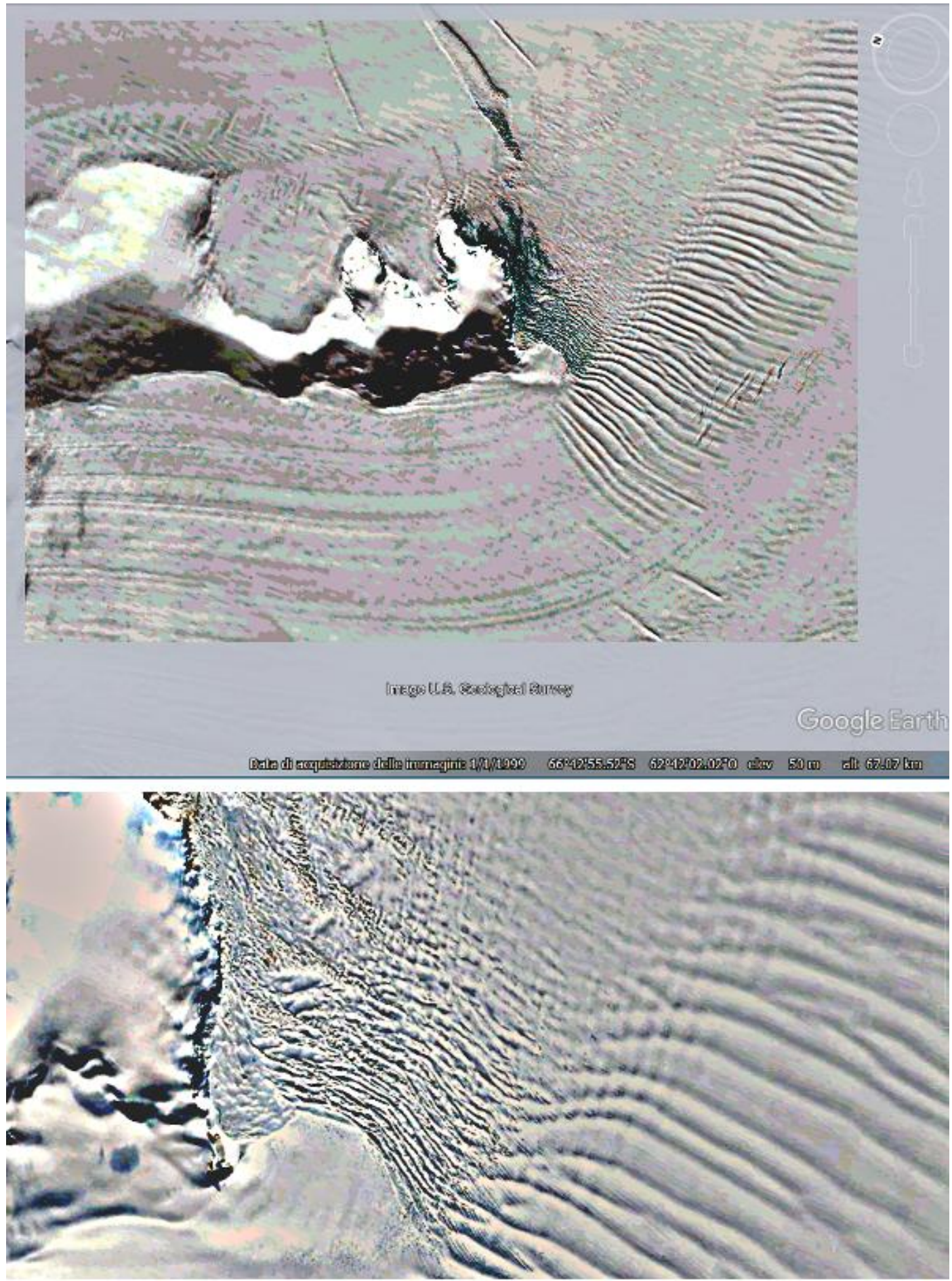

Figure 4: Images from Google Earth enhanced by means of GIMP Retinex. We can see in the upper panel longitudinal and transverse (to the flow) surface structures. A detail is given in the lower part. The transverse textures are interpreted as crevasses in [28]. Coordinates $66^{\circ} 42^{\prime} 55.52^{\prime}$ 'S, $62^{\circ} 42^{\prime} 02.02^{\prime \prime} \mathrm{W}$. 

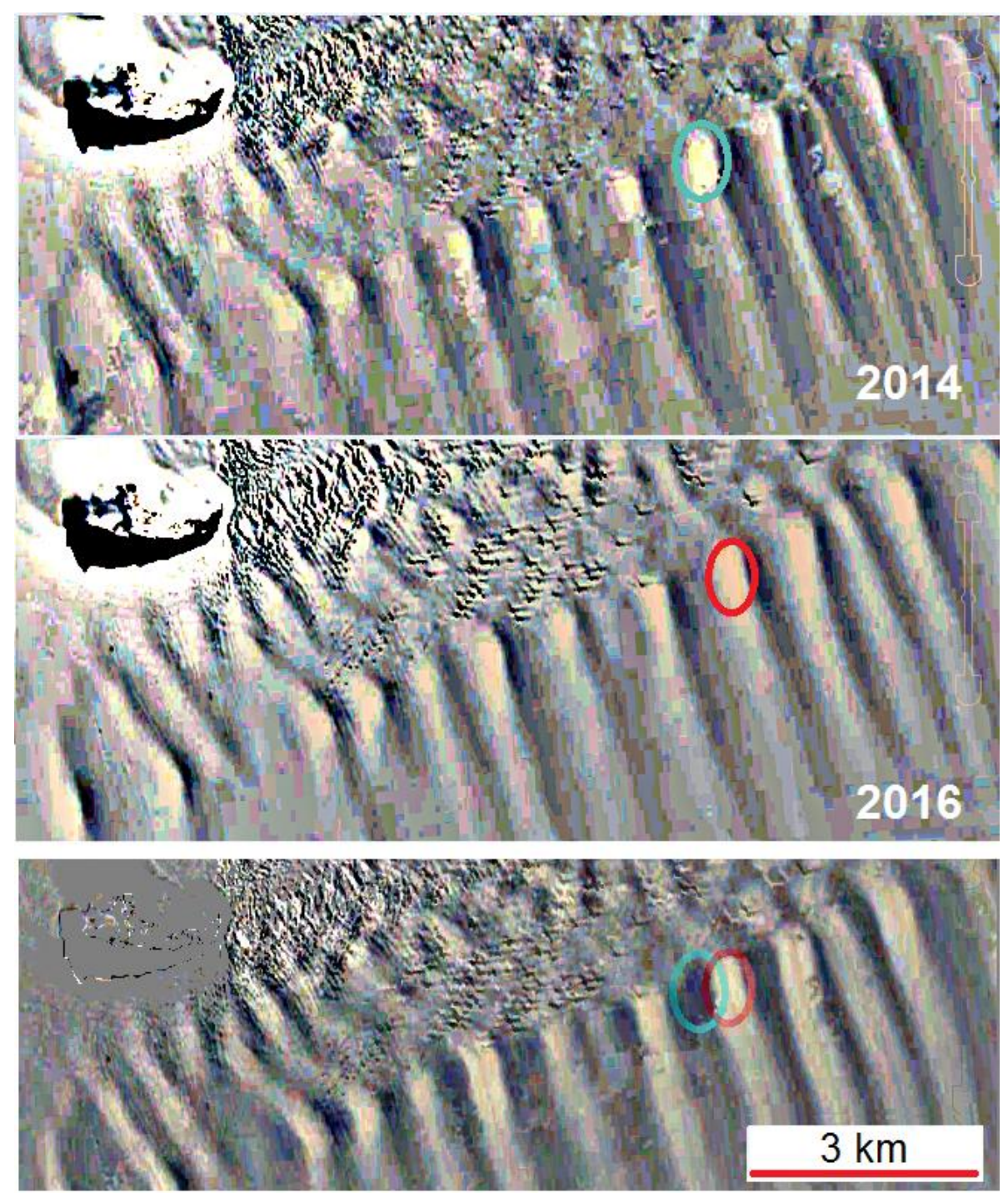

Figure 5: Two images of a time series of Google Earth (2014 and 2016) show the motion of surface features. The red mark points the position of one of them on 31 December 2016, and the blue mark the position of the same feature on 31 December 2014. We can see that the feature moved. Coordinates $67^{\circ} 52^{\prime} 30.08^{\prime}$ 'S, $64^{\circ} 55^{\prime} 03.85^{\prime}$ ' $\mathrm{W}$. 


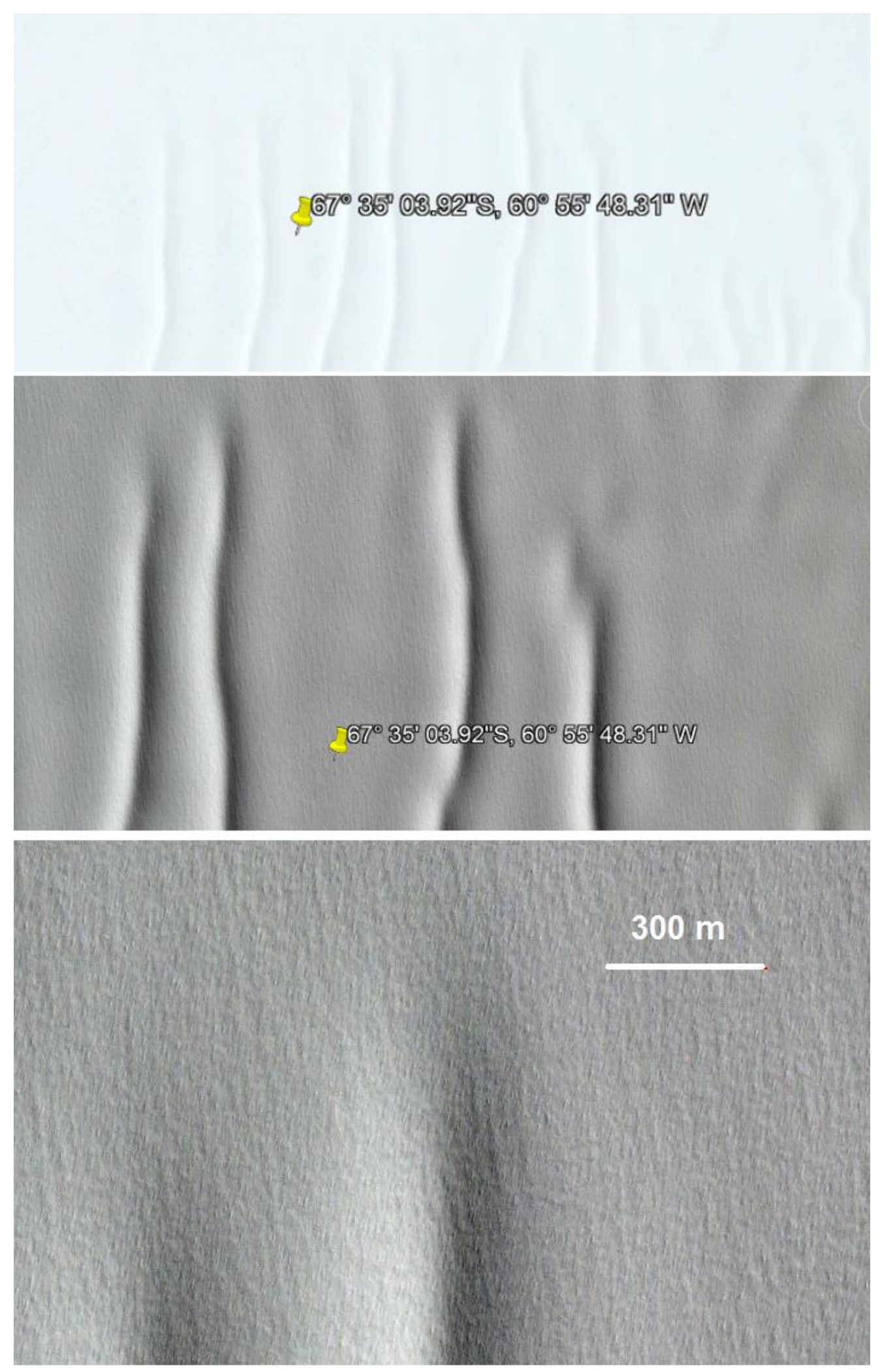

Figure 6: High resolution images from Google Earth at the coordinates $67^{\circ} 35^{\prime} 03.92^{\prime \prime} \mathrm{S}, 60^{\circ} 55^{\prime} 48.31^{\prime \prime} \mathrm{W}$. 


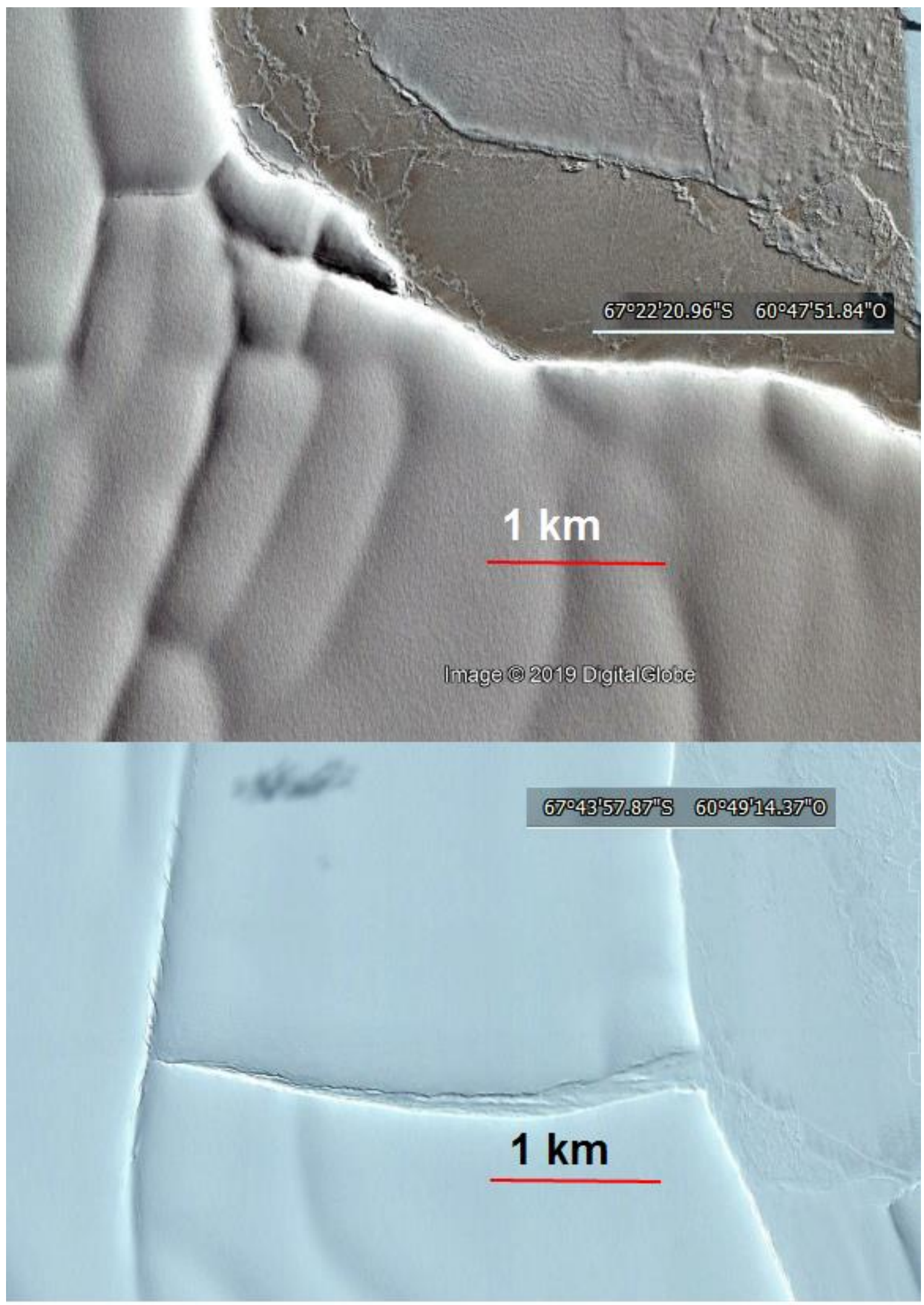

Figure 7: Thanks to Google Earth, we can see what happens to the features, shown in Fig.6, when they reach the edge of the shelf. Textures are interpreted as crevasses [28] and basal crevasses [30]. Upper panel: coordinates

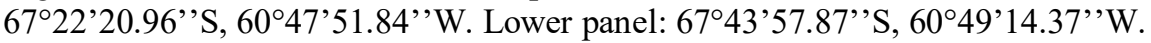

